\title{
Comparison of Digital Copyright Protection on Over the Top (OTT) Streaming Content Media in Indonesia and the United States
}

\author{
Agung Kurniawan Sihombing ${ }^{*}$, Rika Ratna Permata ${ }^{* *}$, Tasya Safiranita Ramli $^{* * *}$ \\ DOI: https://doi.org/10.22304/pjih.v8n2.a2
}

Submitted: February 28, 2021 | Accepted: July 4, 2021

\begin{abstract}
In the rapid technological development, physical boundaries have begun to disappear and the internet has created a 'free culture'. This challenges the concept of copyright along with the emergence of 'digital copyright' objects. Digital copyright objects have become the main commodity of Over-the-Top services which provide means of communication and entertainment through the internet. Content streaming services such as Netflix, use films as well as other cinematographic works as its main commodities. OTT Streaming media helps to protect copyright holders' rights that previously have been violated by illegal streaming sites on the internet. Unfortunately, it also raises a new question: how digital copyrightobjects can be protected in this kind of service. Without physical form, copyright object can be distributed easily on the internet, and it may lead to right violations. To answer this problem, the authors aim to describe the digital copyright protection on OTT Streaming Content Media in Indonesia and compare them to the 1998 Digital Millennium Copyright Act (DMCA) of the United States of America using a descriptive-analytical approach. This study employed a normative juridical approach with secondary data. The results of this study indicate that digital copyright protection in Indonesia is still centered on conventional copyright objects, and a sui generis law is needed to provide better protection for digital copyright objects.
\end{abstract}

Keywords: DMCA, over-the-top services, streaming content.

\section{Perbandingan Perlindungan Hak Cipta Digital pada Media Over The Top (OTT) Streaming Content di Indonesia dan Amerika Serikat}

\footnotetext{
Abstrak

Di era perkembangan teknologi yang sangat pesat, batasan fisik mulai hilang dan internet telah memunculkan 'budaya bebas' yang bisa diakses setiap orang. Hak cipta merupakan

PADJADJARAN Journal of Law Volume 8 Number 2 Year 2021 [ISSN 2460-1543] [e-ISSN 2442-9325]

* Undergraduate Student of the Faculty of Law, Universitas Padjadjaran, Jalan Dipati Ukur Nomor 35 Bandung, S.H. (Universitas Padjadjaran), agungkurniawansihombing@gmail.com.

** Lecturer of the Faculty of Law, Universitas Padjadjaran, Jalan Dipati Ukur Nomor 35 Bandung, Dr. (Universitas Padjadjaran), S.H. (Universitas Padjadjaran), M.H (Universitas Padjadjaran), permata_rika@yahoo.com.

*** Lecturer of the Faculty of Law, Universitas Padjadjaran, Jalan Dipati Ukur Nomor 35 Bandung, Dr. (Universitas Padjadjaran), S.H. (Universitas Padjadjaran), M.H (Universitas Padjadjaran), tasya_safiranita@yahoo.com.
} 
salah satu konsep yang kembali diuji dalam era digital ini dengan kemunculan "hak cipta digital" yang menjadi komoditas utama layanan "Over the Top" yang dapat memberikan sarana komunikasi dan hiburan lewat internet. Salah satu bentuk layanan ini merupakan layanan streaming content, seperti Netflix yang menggunakan film sebagai karya sinematografi sebagai komoditas utamanya. Kehadiran media OTT Streaming Content ini menjadi jawaban bagi perlindungan hak pemegang hak cipta yang selama ini dilanggar dengan situs-situs streaming ilegal di internet, sekaligus memunculkan pertanyaan baru: bagaimana perlindungan hak cipta digital dalam layanan tersebut. Tanpa memerlukan bentuk fisik, tentunya objek hak cipta akan semakin mudah tersebar luas di internet dan berpotensi untuk memunculkan pelanggaran. Atas permasalahan tersebut, penulis akan membahas secara deskriptif analitis mengenai perlindungan hak cipta digital pada Media OTT Streaming Content dalam hukum positif Indonesia, sekaligus memberikan perbandingan dengan Digital Millenium Copyright Act 1998 (DMCA) dari Amerika Serikat yang telah memberikan perlindungan serupa terhadap hak cipta digital. Penelitian ini menggunakan metode pendekatan yuridis normatif dengan jenis data sekunder. Adapun hasil dari penelitian ini menunjukkan bahwa perlindungan hak cipta digital di Indonesia masih berpusat pada objek hak cipta konvensional, sehingga diperlukan peraturan sui generis untuk memberikan proteksi lebih baik terhadap objek hak cipta di era digital.

Kata Kunci: DMCA, konten streaming, layanan over-the-top.

\section{A. Introduction}

In the modern era, technology has narrowed the borderlines between physical and digital plane of the global production system. ${ }^{1}$ The current pace of technological development has led to significant changes to the way people live and work all over the world. The internet has a significant influence on the development. Established exclusively for military purposes under the United States Advanced Research Projects Agency (ARPA) in the $19^{\text {th }}$ century, ${ }^{2}$ the internet has now become a daily necessity for many people in the world.

The Global Digital Reports 2020, in January 2020, reported that more than 4.5 million people, equals to $60 \%$ of the world's population, have used the internet and the figure is expected to increase continuously. ${ }^{3}$ In Indonesia, there are 175.4 million people using the internet. This number increased by 25 million, or about $17 \%$, from the same data in 2019 that figured $64 \%$ of internet penetration. ${ }^{4}$ The internet has various benefits. It affects multiple aspects of life, especially in the way humans find information, communicate, and enjoy entertainment.

\footnotetext{
Sazali Abdul Wahab, "Defining the Concepts of Technology and Technology Transfer: A Literature Analysis", International Business Research, Vol. 5, No. 1, 2012, p. 62.

2 Barry M. Leiner (et.al.), "Brief History of the Internet 1997", 2017, https://www.internetsociety.org/internet/history-internet/brief-history-internet/, accessed on January 2021.

3 Simon Kemp, "Digital 2020: Global Digital Overview", 2020, https://datareportal.com/reports/digital-2020global-digital-overview, accessed on January 2021.

4 Simon Kemp, "Digital 2020: Indonesia", 2020, https://datareportal.com/reports/digital-2020-indonesia, accessed on January 2021.
} 
Lawrence Lessig describes this progress as free culture due to its unlimited and unrestricted utilization. In line with its inclusive nature, the impact of the free culture is also extensive. ${ }^{5}$ The internet has allowed for convergence between the three variables that created the telematics concept: telecommunications, multimedia content, and informatics. In general, telematics can be interpreted as a combination of communication, network system, and information technology. ${ }^{6}$ The telematics law becomes the equivalent of Cyber Law, which is the branch of law that studies the use of information technology. ${ }^{7}$

The branch has become significantly relevant in the digital era since various developments continue to test legal concepts to create certainty and order in society. This is especially true when it comes to the emergence of developing concepts that surround the cyberworld. The world seems to have its own space that is separated from the real world due to its never-ending expansion. However, Lessig argues that, undeniably, there is a need of a regulation that interacts with cyberspace. Various kinds of violations, including copyright piracy, occur from cyberspace. ${ }^{8}$ Therefore, law cannot be entirely separated from the virtual world. ${ }^{9}$

In this digital era, we have seen how objects protected by copyright interact with digital technology in our daily lives. For instance, books were made on physical sheets of paper but now it can be read using smartphone screen. Music and films that were previously only available on $\mathrm{CD}$ or scheduled broadcasts can now be enjoyed anytime and anywhere through electronic devices. These phenomena are digital transformation: a change from analog to digital that affects aspects of business and impacts people's daily lives. ${ }^{10}$

This digitalization has an extraordinary impact on creator and copyright object. It allows an object to be more easily recognized and enjoyed by many people, thus provides a good impact on the creator based on economic perspective. Along with these benefits, challenges also arise. ${ }^{11}$ Groves once addresses this phenomenon: ${ }^{12}$

\footnotetext{
Lawrence Lessig, Free Culture: How Big Media Uses Technology and the Law to Lock Down Culture and Control Creativity, New York: Penguin Press, 2004, p. 8.

6 Hasanuddin Sirait, "Sejarah Perkembangan Teknologi Telematika", 2009, http://astie.staff.gunadarma.ac.id/Downloads/files/50020/sejarah-telematika.pdf, accessed on January 2021.

7 Tasya Safiranita Ramli (et.al.), "Prinsip-Prinsip Cyber Law Pada Media Over the Top E-Commerce Berdasarkan Transformasi Digital di Indonesia", Jurnal Legislasi Indonesia, Vol. 16, No. 3, 2019, p. 393. Lawrence Lessig, Code Version 2.0, New York: Basic Books, 2006, p. 6, 41. 
"Modern telecommunications systems make it possible to pass copyright works from one side of the world to the other almost instantaneously, and to disseminate them at the same time to many users. This creates new opportunities, for the creators of copyright works, to exploit them; it also offers new possibilities for those who would infringe their rights."

This statement is particularly relevant to the emergence of Over the Top (OTT) Streaming Content services. For instance, Netflix makes people accessing various films anywhere and anytime. OTT is a form of service delivered via the internet that crosses network operators, competes with telecommunications operators' services, and affects networks and services. ${ }^{13}$ There are two main types of streaming services, namely live streaming and pre-recorded streaming. Netflix, particularly, is a pre-recorded one, which also known as a Video on Demand (VOD) service. This service has proliferated and has become one of the primary entertainment media providing cinematographic works. ${ }^{14}$

The emergence of the OTT media is a solution to the problems of copyright infringement through illegal websites. This is because, unlike illegal websites, the service grants royalties to copyright and other related-rights holders. It can be a better alternative to watch movies and support the creators of the cinematographic work. ${ }^{15}$ On the other hand, the service also offers a more convenience way to users to watch movies legally, other than going to the theatres or buying a DVD.

It comes as no surprise that the government supports streaming content services that distribute films, such as Netflix and the like. The government's support is shown by the distribution of more than 5 million set-top boxes for free to underprivileged people to accelerate digitalization in the public's infrastructure sector. ${ }^{16}$ The set-top box allows the conversion of digital networks to television, so that people can enjoy movies from services such as Netflix from their analog TV. ${ }^{17}$

13 Shirley Baldry (et.al.), "The Rise of OTT Players - What Is the Appropriate Regulatory Response?", $25^{\text {th }}$ European Regional Conference of the International Telecommunications Society (ITS): "Disruptive Innovation in the ICT Industries: Challenges for European Policy and Business", Brussels, Belgium, $22^{\text {nd }}-25^{\text {th }}$ June, 2014, International Telecommunications Society (ITS), 2014, p. 7.

14 Shaikh Ayaz, "The Rise of OTT: Why 2020 was a Game-Changer for Streaming Aces like Netflix and Amazon Prime Video", https://indianexpress.com/article/entertainment/opinion-entertainment/why-2020-was-agame-changer-for-streaming-aces-like-netflix-and-amazon-prime-video-7105424/, accessed on January 2021.

15 Denico Doly, "Penegakan Hukum terhadap Pembuat Situs Streaming Film Bajakan", Puslit, Vol. XII, No. 1, 2020, p. 4.

16 Mochammad Rizki, "Dukung TV Digital, Pemerintah Siapkan 5,37 Juta Set Top Box Gratis", 2020, https://www.nusantaratv.com/nasional/fokus/dukung-tv-digital-pemerintah-siapkan-537-juta-set-top-boxgratis, accessed on January 2021.

17 Kominfo, "UU Cipta Kerja Dukung Percepatan Transformasi Digital dan Ciptakan Lapangan Kerja Baru Sektor Kominfo, Siaran Pers No. 127/HM/KOMINFO/10/2020", 2020, https://www.kominfo.go.id/content/detail/29924/siaran-pers-no-127hmkominfo102020-tentang-uu-ciptakerja-dukung-percepatan-transformasi-digital-dan-ciptakan-lapangan-kerja-baru-sektorkominfo/0/siaran_pers, accessed on January 2021. 
On the other hand, the advancement of the OTT Streaming Content service is a relatively new phenomenon in the cyberlaw field that deserves further examination, especially in the use of copyright objects. Although the implementation is not per se a violation of law, the use of digital copyright objects in OTT Streaming Content services is a new implementation that will continue to develop in the future. In addition, it is essential to remember that copyright infringement can occur due to the system providers' negligence and outsiders' crimes who may hack the operating system. To address this challenge, it is necessary to combine cyberlaw and copyright law concepts, which is quite challenging to the Indonesian legal system.

Internationally, copyright protection has existed since the Paris Convention for The Protection of Industrial Property (Paris Convention) in 1883, followed by the International Convention for the Protection of Literary and Artistic Works (Bern Convention) in $1886 .{ }^{18}$ In Indonesia, copyright protection has existed since the Dutch colonial era based on Auterswet 1912. Currently, the copyright protection in Indonesia is based on the Law Number 28 of 2014 on Copyright (Copyright Law). However, this law does not recognize the concept of 'digital copyright', which demands the integration of copyright protection into technology. On the other hand, the Law Number 11 of 2008 on Electronic Information and Transactions as amended by the Law Number 19 of 2016 (the EIT Law) as the regulation for Indonesian cyberlaw has not completely regulated digital copyright protection.

At the international level, the copyright protection in the digital era has been addressed in the World Intellectual Property Organization (WIPO) Copyright Treaty (WCT) 1996, which was established cumulatively with the WIPO Performances and Phonograms Treaty (WPPT) 1996. Both are referred to as "WIPO Internet Treaties". At the national level, the United States of America (USA, hereinafter referred to as the US), which has ratified WCT, also provides a specific regulation that protect digital copyright. It is the 1998Digital Millennium Copyright Act (DMCA), which adopts the idea of combining copyright and electronic media. ${ }^{19}$ Further, the DMCA has also become the foundation of protection implemented by largest OTT

\footnotetext{
18 Muhammad Djumhana and R. Djubaedillah, Hak Milik Intelektual: Sejarah Teori dan Prakteknya di Indonesia, Bandung: PT Citra Aditya Bakti, 2003, p. 12.

19 Pujiyono and Sufmi Dasco Ahmad, "Legal Protection for Creators of Cinematographic Works against Copyright Infringement through Streaming and Free Download Sites", Journal of Legal, Ethical and Regulatory Issues, Vol. 2, No. 3, 2019, p. 4.
} 
companies globally, such as Facebook, YouTube, Yahoo, and Netflix. The DMCA has a significant influence on content protection practices. ${ }^{20}$

This paper discusses the protection of digital copyright law in the digital transformation era within Indonesian context. It mainly focused on the use of cinematographic copyright objects in the pre-recorded OTT streaming content media services. This analysis includes the Indonesian copyright protection and cyber law regimes and provides in the comparisons with the 1998 DMCA, which had earlier adopted the concept. Moreover, this paper also gives an overview of the use of digital copyright objects practices applied by OTT Streaming Content providers such as Netflix to truly comprehend the implementation.

\section{B. The Emergence of Digital Copyrights and Their Functions in the OTT Streaming Media}

\section{Digitalization of Copyright Objects}

Copyright law first appeared in the world following the invention of the printing press by J. Gutenberg in Europe, on $15^{\text {th }}$ century. This invention enables the easy creation of written works and reproduce them mechanically. Then, the concept of rights to copy grew. ${ }^{21}$ The idea of copyright that was first implanted in copyright protection law was conventional copyright, which required a physical medium.

Copyright is a form of incentive and reward given to creators of written works, arts, literature, and scientific works. This right adds spirits for creators to produce their works and becomes a reward for the benefits of their work. Regulation is provided to guarantee creators to control and enjoy their works exclusively. It proves that legal protection is an interest of copyright owners, either individual or group. 22

The Black's Law Dictionary defines copyright as follows. ${ }^{23}$

"The right of literary property as recognized and sanctioned by positive law. A right granted by the statute to the author or originator of certain literary or artistic productions, whereby he is invested, for a limited period, with the sole and exclusive privilege of multiplying copies of the same and publishing and selling them."

The advancement of digital technology has influenced creative works in the digital era through digitalization. Digitalization is the most significant technological trend that can change social and business aspects. Today, almost every business sector is

\footnotetext{
20 Moch Zairul Alam, "Perbandingan Perlindungan Sarana Kontrol Teknologi Atas Ciptaan Menurut Ketentuan Hak Cipta di Indonesia dan Amerika Serikat", Legal Spirit, Vol. 2, No. 1, 2018, p. 102.

Yusran Isanaini, Hak Cipta dan Tantangannya di Era Cyber Space, Bogor: Ghalia Indonesia, 2009, p. 8.

Tim Lindsey, (et.al.), Hukum Kekayaan Intelektual, Bandung: PT Alumni, 2019, pp. 89-90.

Bryan A. Garner, Black's Law Dictionary, Seventh Edition, St. Paul, MN: Thomson Reuters, 1999, p. 337.
} 
encouraged to take advantage of digital technology to adapt to this new reality. ${ }^{24}$ Hagberg describes digitalization as follows. ${ }^{25}$

"Both to a transformation from 'analogue' to 'digital' (e.g. a shift from cash to electronic payments) and to the facilitation of new forms of value creation (e.g. Accessibility, availability, and transparency). Employing the notion of 'digitalization' rather than 'digital' implies that this transformation is on-going and has no clear beginning or end."

The digitalization process works by converting all information obtained from the real world into a series of binary numbers that forms data in digital codes. A computer manipulates the digital code series to produce results in forms of text, images, and videos. This conversion has various benefits, providing ease of electronic duplication, distribution, compression, and encryption. The first three benefits combined will be challenges for copyright holders. On the other hand, the last benefit will help to protect the works from irresponsible use. ${ }^{26}$

The result of this transformation is known as digital copyright, which must be protected by copyright law. ${ }^{27}$ Litman describes digital copyright as the inherent right of copyrighted objects that become digital through technology's assistance, which can move places through intangible objects, such as broadcast transmissions and internet networks. ${ }^{28}$ These copyrighted objects can easily be distributed in various parts of the world via the internet as digital contents.

This digitalization of copyright encourages the renewal of regulatory concepts that can create protection for copyright objects in the digital era to respect creators and enable the public to access the copyrighted works. For example, in the increasing ease of use and distribution of copyright objects, Collective Management Institute (CMI) was founded with a task to collect and to manage royalty from users of copyright works. The renewal of regulatory concepts is very important in ensuring legal certainty and order in using digital copyright objects. In

24 João Reis (et.al.), "Digitalization: A Literature Review and Research Agenda", Proceedings on 25th International Joint Conference on Industrial Engineering and Operations Management - IJCIEOM, 2020, p. 443.

25 J. Sundstrom Hagberg, (et.al.), "The Digitalization of Retailing: An Exploratory Framework", International Journal of Retail \& Distribution Management, Vol. 44, No. 7, 2016, p. 694.

26 Stephen M. Kramarsky, "Copyright Enforcement in the Internet Age: The Law and Technology of Digital Rights Management", DePaul Journal of Art, Technology \& Intellectual Property Law, Vol. 11, No. 1, 2001, p. 4. Moch Zairum Alam, op.cit., p. 99.

28 Jessica Litman, Digital Copyright, New York: Prometheus Book, 2006, pp. 16-18. 
addition, Reidenberg also stated that, as copyright objects have integrated into the digital space, technical protection is also needed in protecting copyright rights in the digital era. ${ }^{29}$ Therefore, law and technology must work side by side.

\section{Copyright Object in the OTT Streaming Content Services}

OTT services is an evidence of the existence of digital transformation and developments in the telematics sector. ${ }^{30}$ The emergence of this service is closely related to major technical breakthroughs in consumer electronics and increased network capabilities in terms of speed (especially for video services). In Indonesia, the emergence of OTT media is strongly influenced by the emergence of telecommunications liberalization, allowing diversity in the telecommunications service provider sector, which eventually opens opportunities for OTT service providers to operate in the country. ${ }^{31}$

Based on the ASEAN International Telecommunication Union (ITU) report on the Over-the-Top Project, OTT is defined as follows. ${ }^{32}$

"OTT (Over-the-top) refers to a form of services delivered via the Internet which bypass the traditional network service provider, compete with services offered by the telecom operators, and/or affect the quality of networks and service. "

From this definition, we can conclude that OTT service is a form of service delivered through the internet that crosses network operators. One cannot equate this service with conventional broadcasting operations, which require a transmitter or transmission line..$^{33}$ In other words, this service can operate by 'hitching a ride' with network service providers in states of the world to provide its services worldwide without having a physical presence in respective countries. ${ }^{34}$

In Indonesia, an OTT service is recognized as an 'application services and/or content through the internet'. ${ }^{35}$ This is in accordance with the Circular Letter of the

29 Joel R. Reidenberg, "Lex Informatica: The Formulation of Information Policy Rules through Technology", Texas Law Review, Vol. 76, 1997, pp. 565-568.

30 Vincent Bullich and Thomas Guignard, "OTT Strategies and Regulations: Lessons from the US (2005-2015)", Quaderns del CAC 42, Vol. XIX, p. 6.

31 Danrivanto Budhijanto, Hukum Telekomunikasi, Penyiaran \& Teknologi Informasi: Regulasi dan Konvergensi, Bandung: PT Refika Aditama, 2010, p. 36.

32 Bui Thu $\mathrm{Ha}$, "ASEAN Report on OTT Project", ITU-ASEAN Forum on OTT Services: Business, Policy and Regulatory Trends 08-09 December 2015, Phnom Penh, Cambodia, 2015, https://www.itu.int/en/ITUD/Regional-Presence/AsiaPacific/Documents/Events/2015/Dec-

OTT/Presentations/Presentation\%20of\%20ASEAN\%200TT\%20project\%20THU\%20HA.pdf, accessed on January 2021.

33 Matthew Syrkin, "U.S. Television on the Internet and the New 'MVPDs'" https://www.hugheshubbard.com/news/u-s-television-on-the-internet-and-the-new-mvpds-updated, accessed January 2021. See also Constitutional Court Decision Number 39/PUU-XVIII/2020 Concerning the Review of Law Number 32 of 2002 concerning Broadcasting Against the 1945Constitution of the Republic of Indonesia, pp. 269-270.

34 Shirley Baldry (et.al.), loc.cit.

35 Compare to Article 25 EIT Law. 
Minister of Communication and Information Technology (MOCl) Number 3 of 2016 on the Provision of Application Services and/or Content through the Internet (Over the Top) (Circular 3/2016). Point 5.1 defines Content Services via the Internet as follows. ${ }^{36}$

"The provision of all forms of digital information consisting of text, sound, images, animation, music, videos, films, games (games) or a combination of some and/or all of them, including in the form that is streamed (streamed) or downloaded by utilizing telecommunications services through internet protocol-based telecommunications networks."

Based on Article 1 point 3 of the $\mathrm{MOCl}$ Regulation Number 9 of 2017 on the Implementation of Content Providing Services on Cellular Mobile Networks, Content is as follows. ${ }^{37}$

"All forms of information that can be in the form of text, images, sound, animation, or a combination of all in digital form, including application software for download."

The term 'streaming' refers to a technology for playing video or audio files, either directly or pre-recorded, from a web server. The method of live streaming allows multimedia files to be played without having to be downloaded fully and in real time. Pre-recorded streaming involves recording at an earlier time for later transmission and allowing subscribers to play the content at their preferred time. ${ }^{38}$

Content is an object contained in electronic media that becomes the main object or commodity. Content usually covers copyright protection objects, such as sounds, images, photos, or videos that are used by electronic media users to share information or communicate electronically on the Internet. People can use the content to share information, expression, opinion, or simply as a means of entertainment. In the OTT Streaming Content service, content refers to films that are objects of copyright protection (cinematographic works).

Up to now, the OTT Streaming Content services have continued to increase and have threatened the existence of conventional broadcasting services. The

Point 5.1. of Circular 3/2016.

37 Article 1 point 3 of the $\mathrm{MOCl}$ Regulation Number 9 of 2017 on the Implementation of Content Providing Services on Cellular Mobile Networks.

38 Aida Suraya Md. Yunus (et.al.), "Use of Webcasting Technology in Teaching Higher Education", International Education Journal, Vol. 7, No. 7, 2006, p. 917. 
streaming technology available in the OTT service allows users to enjoy the contents in the form of films that are directly executed on the users' devices following request from the user without the need to go through a download process that usually makes the user wait longer. ${ }^{39}$ The wide variety of content are offered and can be accessed easily, being the main advantages of the service.

The example of copyright use on the OTT Streaming Content service is represented by Netflix. Netflix face a tough competition with similar service providers such as Amazon Prime, Hulu, and Disney+. ${ }^{40}$ It was founded in 1997 by two software engineers, Reed Hastings and Marc Rudolph, as an online DVD delivery service. ${ }^{41}$ In 2007, for the first time, Netflix began to broadcast films and TV series. They are streamed directly to the Personal Computer (PC). Netflix does not rely on advertisement to collect revenue. They rely on subscription fees from their subscribers. ${ }^{42}$

In providing content, Netflix negotiates with producers of TV shows and film producers. Licensing content allows the owner of a TV show or film to stream content through their services. The company also has its original content since $2011 .{ }^{43}$

\section{Digital Copyright Legal Protection in the 1998 DMCA}

The shift from physical form to digital objects has removed physical barriers to exploitation. It makes it easier for creators to distribute their work, and at the same time, creates new challenges to their rights. ${ }^{44}$ Everyone has the potential to commit copyright infringement on the internet. This challenge in cyber law is crucial to be regulated in a sui generis regulation. ${ }^{45}$

Contrary to Indonesia, the US has been aware of the convergence between digital media copyright that needs to be addressed in the legal system. The US has enacted the Digital Millennium Copyright Act (DMCA), which is also a form of the

\footnotetext{
39 Askari Azikin and Yudha Purwanto, Video/TV Streaming dengan Audio Lan Project, Yogyakarta: Andi Offset, 2005, pp. 1-2.

40 Dan "Who "Whowitz, Metflix's Main Competitors?", https://www.investopedia.com/articles/markets/051215/who-are-netflixs-main-competitors-nflx.asp, accessed on January 2021.

41 Michael L Wayne, "Netflix, Amazon, and Branded Television Content in Subscription Video On-Demand Portals", Media, Culture \& Society, Vol. 40, No. 5, 2017, p. 9.

42 Ellavie Ichlasa Amalia, "Awal Mula Netflix, dari Rental Film Fisik sampai Digital", https://www.medcom.id/teknologi/news-teknologi/DkqD1gnb-awal-mula-netflix-dari-rental-film-fisiksampai-digital, accessed on January 2021.

43 Brian Beers, "How Netflix Pays for Movie and TV Show Licensing", https://www.investopedia.com/articles/investing/062515/how-netflix-pays-movie-and-tv-showlicensing.asp\#citation-6, accessed on February 2021.

44 Stephen M. Kramarsky, op.cit, p. 8.

45 Danrivanto Budhijanto, Cyber Law dan Revolusi Industri 4.0, Bandung: Logoz Publishing, 2019, pp. 2-3.
} 
US' commitment to the ratification of the WCT in $1996 .{ }^{46}$ At the DMCA attestation speech, President Bill Clinton says as follows. ${ }^{47}$

"American copyright-based industries that produce and promote creative and high-technology products contribute more than $\$ 60$ billion annually to the balance of U.S. trade. This bill will extend intellectual protection into the digital era while preserving fair use and limiting infringement liability for providers of basic communication services."

There are at least three breakthrough rules in the DMCA, namely anticircumvention, safe harbor doctrine, and takedown procedure. They can be further elaborated as follows.

\section{Anti-circumvention}

The DMCA provides that a copyright owner can apply Technological Protection Measure (TPM) to protect copyrighted works from copy and unauthorized access to their works. This is one of the mandates of Article 11 of the WCT as follows. ${ }^{48}$

"Contracting Parties shall provide adequate legal protection and effective legal remedies against the circumvention of effective technological measures that are used by authors in connection with the exercise of their rights under this Treaty or the Berne Convention and that restrict acts, in respect of their works, which are not authorized by the authors concerned or permitted by law. "

Copyright owners can also embed rights management information in their work to manage their rights in the digital realm. This 'anti-circumvention' prohibits a third party from acting in circumvention of TPM and rights management information with circumvention techniques and devices. ${ }^{49}$

\section{Safe Harbor}

The DMCA aims is to balance rights among creators, operators of electronic systems, and internet users. The Safe Harbor reflects the aim, particularly for electronic system operators. 'Safe Harbor' is a set of conditions that allows

46 Charles K. Lane, "The DMCA's Safe Harbor Provision: Is It Really Keeping the Pirates at Bay?", Wake Forest Journal of Business and Intellectual Property Law, Vol. 14, No. 1, 2013, p. 195.

47 Robert N. Diotalevi, "The Digital Millennium Copyright Act", https://www.westga.edu/ distance/ojdla/summer32/diotalevi32.html, accessed on January 2021.

48 Article 11 of the WCT.

49 Tana Pistorius and Odirachukwu S. Mwim, "The Impact of Digital Copyright Law and Policy on Access to Knowledge and Learning", Journal of the Reading Association of South Africa, Vol. 10, No. 1, 2019, p. 2. 
electronic system providers to be 'immune' to liability for possible violations of copyright by taking certain specific steps to cooperate with copyright holders in enforcing their rights. ${ }^{50}$

\section{Takedown Procedure}

This point provides that once a service provider receives information of infringing copyright content, either through notification from the copyright holder or on its behalf, the service provider must immediately remove the content to comply with safe harbor rules. In the DMCA, there is no step in this procedure that requires the service provider to verify the status of the claimed copyrighted content. Thus, after the service provider notifies its customer that their material has been removed based on the DMCA takedown notification, the suspect who upload the infringing content is permitted to submit a counter-notification by providing certain information to defend his/her stand. ${ }^{51}$

In addition, the DMCA is not free from public criticism. Patricia Schroeder, CEO of the Association of American Publishers (AAP), in the 2001 WIPO International Conference, says as follows. ${ }^{52}$

"Many technology companies opposed the DMCA, calling it a 'publishers' model that would destroy the 'open model' of the Internet. That meant our insistence that intellectual property owners be protected from piracy made us the enemies of 'openness'."

The criticism is given specifically to the 'anti-circumvention' provisions that limit innovation and competition among companies and limit the use of copyright objects for research purposes as a part of fair use. ${ }^{53}$ Regarding the 'Safe Harbor' provision, some parties also argue that this could be a bad precedent to allow the providers to determine their own obligations and reject their accountability. ${ }^{54}$ However, some also support the existence of those provisions. In this view, the DMCA draws on a common-sense: it is wrong to crack the lock on digital content and the technological devices that allow this should be prohibited. Not only wrong; it is bad for the economy. ${ }^{55}$

\section{Protection of Digital Copyright Law to the Cinematographic Works on the OTT Media Streaming Content based on Indonesian Positive Law}

\footnotetext{
$50 \quad 17$ U.S.C. § 512 (2000); Mike Scott, "Safe Harbors under the Digital Millennium Copyright Act", Legislation and Public Policy, Vol. 9, No. 99, 2005, p. 100.

51 Charles K. Lane, op.cit, p. 199.

52 PBwork, "Pros and Cons", dmca.pbworks.com/w/page/17963779/Pros\%20and\%20Cons, accessed on February 2021.

Ibid.

Mike Scott, op.cit, p. 100.

PBwork, loc.cit.
} 


\section{Digital Copyright Protection in the Indonesian Copyright Law and Cyber Law Regime}

During the rapid growth of digital technology and the massive use of copyright objects on the internet, legal protection must provide legal certainty and encourages creators' creativity. $^{56}$ This is in accordance with Mochtar Kusumaatmadja's Legal Theory of Development, in which legal protection aims to guarantee certainty and order to create a legal function as a means of reforming society. ${ }^{57}$

In terms of digital copyright protection in Media OTT Streaming Content in Indonesia, this topic must be discussed in conjunction with two legal regimes: copyright law and cyber law. Copyright protection in Indonesia is mainly regulated in the Copyright Law, while the "umbrella regulation" of Indonesian cyberlaw is held in the EIT Law.

The definition of copyright is contained in Article 1 paragraph (1) of the Copyright Law as follows. ${ }^{58}$

"The exclusive rights of an author that arise automatically based on the declarative principle after a work is manifested in a tangible form without reducing restrictions in accordance with the provisions of laws and regulations."

Based on the definition, copyright protection appears automatically without registration in Indonesia. This right includes both moral and economic rights..$^{59}$ Moral rights are rights inherent with the creator and cannot be transferred..$^{60}$ Meanwhile, economic rights are not always "attached" to work, but it is transferable, for example by licensing them to other parties through royalties. ${ }^{61}$

One of the objects of creation in copyright protection is a work of cinematography, which is defined as follows. ${ }^{62}$

"Cinematographic works are creations in the form of moving images, including documentary films, commercial films, reportages or story

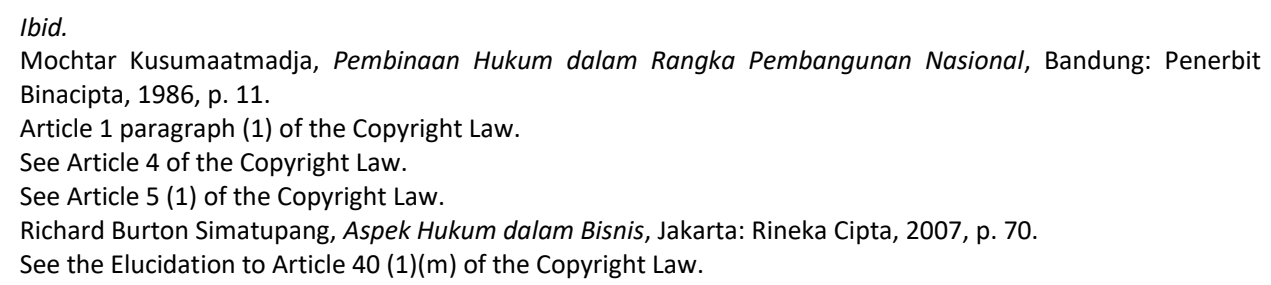


films made with scenarios, and cartoon films. Cinematographic works can be made on celluloid tapes, videotapes, video discs, optical discs and/or other media that are possible to be shown in theaters, big screens, television, or other media. Cinematography is an example of an audiovisual form."

The pivotal points of the copyright protection are always moral and economic rights. To protect moral rights, Article 6 of the Copyright Law stipulates that creator can have Copyright management information and copyright electronic information contained in the copyright object. ${ }^{63}$ In these two forms of information, data regarding creator, creation, and other relevant matters to the digital creation are embedded in the digital works. ${ }^{64}$ For economic rights, Article 8 regulates that creators or copyright holders are entitled to economic benefits for works, including in publishing works, copying works in all their forms, and displaying works. ${ }^{65}$

The presence of copyright objects in the digital media has already been acknowledged in the regulation. Article 52 regulates the prohibition of damaging, destroying, eliminating, or rendering the technology control facilities used as protection for Works or Related Rights products and protection of Copyright or Related Rights, except for the interests of state defense and security. ${ }^{66}$ Furthermore, to prevent violations of Copyright and Related Rights through information technology-based means, Article 54 regulates the government's authority to: ${ }^{67}$

1) Supervise the creation and dissemination of content violations of copyright and related rights;

2) Cooperate and coordinate with various parties, both domestic and foreign, in the prevention of creation and dissemination of content violations of Copyright and Related Rights;

3) Monitor recording actions using any media of Works and Related Rights products at a performance venue.

On the other hand, the cyberlaw regime in Indonesia is generally regulated in EIT Law. In relation to electronic media service systems, digital content can be equated with electronic information. Article 1 paragraph (1) of the Law is defined as follows. ${ }^{68}$

"Electronic information is one or a set of electronic data, including but not limited to writing, voice, images, maps, designs, photos, electronic data interchange (EDI), electronic mail, telegram, telex, telecopy or the

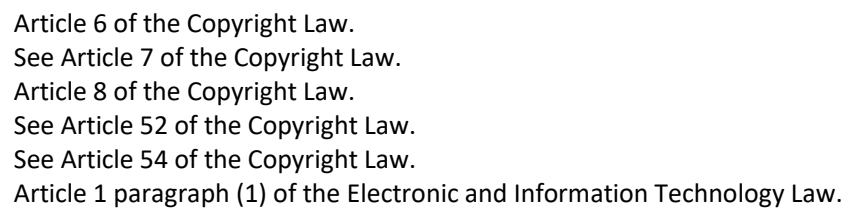


like, letters processed, signs, numbers, Access Codes, symbols, or perforations that have meaning or can be understood by those who are able to understand them."

In line with that, Article 25 of the EIT Law also regulates as follows. ${ }^{69}$

"Electronic Information and/or Electronic Documents compiled into intellectual works, internet sites, and intellectual works contained therein are protected as Intellectual Property Rights under the provisions of the Laws and Regulations."

This article also serves as a legal basis of content regulation in digital media. Similarly, Circular $3 / 2016$ as the only regulation that provides guidance for the implementation of OTT also stipulates the prohibition of content that can encourage the public to act against the law, including against violations of intellectual property rights. $^{70}$

There are also other relevant technical regulations as follows.

1. The Government Regulation Number 71 of 2019 on the Implementation of Electronic Systems and Transactions (The Government Regulation Number 71/2019) as the main technical regulation for the administration of electronic systems.

2. Joint Regulation of the Minister of Law and Human Rights and the Minister of Communication and Information Technology Number 14 of 2015 and Number 26 of 2015 dated July 2, 2015, on the Implementation of Closure of Content and/or User Access Rights Violation of Copyright and/or Related Rights in Electronic Systems (Joint Regulation 14/2015, 26/2015) that regulates the technical reporting and closure of content for the violation on copyright and other related rights in Indonesia.

3. The Circular Letter of the Minister of Communication and Information Technology Number 5 of 2016 on the Limitations and Responsibilities of Platform Providers and Merchants in E-Commerce by Using User-Generated Content Platforms. It provides guidelines for limiting liability for violations of ecommerce providers in the form of User Generated Content (UGC).

Article 25 of the Electronic and Information Technology Law.

Point 5.6 Circular Number 3 of 2016. 
Through comparison between digital copyright law protection in the US and Indonesia, the following table explain the detailed points of regulation.

Table 1. Comparison of Digital Copyright Protection in the US and Indonesia

\begin{tabular}{|c|c|c|c|}
\hline No. & $\begin{array}{l}\text { Points of } \\
\text { Regulation }\end{array}$ & United States (DMCA) & $\begin{array}{c}\text { Indonesia (Copyright Law and } \\
\text { Cyberlaw regime) }\end{array}$ \\
\hline 1. & $\begin{array}{l}\text { Anti- } \\
\text { circumvention } \\
\text { (Technology } \\
\text { Control Advice) }\end{array}$ & $\begin{array}{l}\text { 1201.a.1 DMCA } \\
\text { No person shall } \\
\text { circumvent a technological } \\
\text { measure that effectively } \\
\text { controls access to a work } \\
\text { protected under this } \\
\text { title. The prohibition } \\
\text { contained in the preceding } \\
\text { sentence shall take effect } \\
\text { at the end of the 2-year } \\
\text { period beginning on the } \\
\text { date of the enactment of } \\
\text { this chapter. }\end{array}$ & $\begin{array}{l}\text { Article } 52 \text { of the Copyright } \\
\text { Law } \\
\text { Every person is prohibited from } \\
\text { damaging, destroying, } \\
\text { eliminating, or rendering the } \\
\text { technological control facilities } \\
\text { used as protection for Works or } \\
\text { Related Rights products as well } \\
\text { as protection of Copyright or } \\
\text { Related Rights, except for the } \\
\text { interests of state defense and } \\
\text { security, as well as for other } \\
\text { reasons in accordance with the } \\
\text { provisions of law and } \\
\text { regulations or other } \\
\text { agreements. }\end{array}$ \\
\hline 2. & $\begin{array}{l}\text { Safe Harbor } \\
\text { Provision }\end{array}$ & $\begin{array}{l}512 \text { (c) (1) (A) - (C) Online } \\
\text { Copyright Infringement } \\
\text { Liability Limitation Act } \\
\left(\text { OCILLA) }{ }^{73}\right. \\
\text { (A) (i) does not have actual } \\
\text { knowledge that the } \\
\text { material or an activity } \\
\text { using the material on the } \\
\text { system or network is } \\
\text { infringing; (ii) in the } \\
\text { absence of such actual } \\
\text { knowledge, is not aware of } \\
\text { facts or circumstances } \\
\text { from which infringing } \\
\text { activity is apparent; or } \\
\text { (iii) upon obtaining such } \\
\text { knowledge or awareness, } \\
\text { acts expeditiously to } \\
\text { remove, or disable access }\end{array}$ & $\begin{array}{l}\text { Article } 43 \text { of the Copyright Law } \\
\text { d) creation and dissemination } \\
\text { of Copyright content } \\
\text { through information and } \\
\text { communication technology } \\
\text { media that are non- } \\
\text { commercial and/or } \\
\text { beneficial to the Author or } \\
\text { related parties, or the } \\
\text { Author expresses no } \\
\text { objection to the creation } \\
\text { and creation and } \\
\text { dissemination of Copyright } \\
\text { content through non- } \\
\text { commercial information } \\
\text { and communication } \\
\text { technology media and/or } \\
\text { benefit the Author or } \\
\text { related parties, or the }\end{array}$ \\
\hline
\end{tabular}

17 U.S. C. § 1201.a.1.

Article 52 of the Copyright Law.

17 U.S.C. § 512(c)(1)(A)-(C) (2006). 


\begin{tabular}{|c|c|c|c|}
\hline & & $\begin{array}{l}\text { to, the material; } \\
\text { (B) does not receive a } \\
\text { financial benefit directly } \\
\text { attributable to the } \\
\text { infringing activity, in a case } \\
\text { in which the service } \\
\text { provider has the right and } \\
\text { ability to control such } \\
\text { activity; and } \\
\text { (C) upon notification of } \\
\text { claimed infringement as } \\
\text { described in } \\
\text { paragraph (3), responds ex } \\
\text { peditiously to remove, or } \\
\text { disable access to, the } \\
\text { material that is claimed to } \\
\text { be infringing or to be the } \\
\text { subject of infringing } \\
\text { activity. }\end{array}$ & $\begin{array}{l}\text { Author expresses no } \\
\text { objection to the making } \\
\text { and distribution of such } \\
\text { distribution. } \\
\text { Article } \mathbf{1 5} \text { of the ElT Law }{ }^{74} \\
\text { (1) Every Electronic System } \\
\text { Operator must operate an } \\
\text { Electronic System reliably } \\
\text { and safely and be } \\
\text { responsible for the proper } \\
\text { operation of the Electronic } \\
\text { System. } \\
\text { (2) Electronic System Operator } \\
\text { is responsible for its } \\
\text { Electronic System } \\
\text { Operation. } \\
\text { (3) The provision as intended } \\
\text { in paragraph (2) does not } \\
\text { apply if it can be proven } \\
\text { that there is a force, error, } \\
\text { and/or negligence of the } \\
\text { Electronic System user. } \\
\text { Circular } 5 / 2016 \text { 75 } \\
\text { 2. The responsibilities of the } \\
\text { UGC Platform Provider include: } \\
\text { a. Responsible } \\
\text { administering electronic } \\
\text { systems and managing } \\
\text { content on the Platform in } \\
\text { a reliable, secure and } \\
\text { responsible manner. } \\
\text { The provisions of letter (a) } \\
\text { above do not apply if it can } \\
\text { beroven and/or negligence on }\end{array}$ \\
\hline
\end{tabular}

74 Article 15 of the Electronic and Information Technology Law.

75 Point V. C. 2 (a) (b) of Circular 5 of 2016. 


\begin{tabular}{|c|c|c|c|}
\hline & & & $\begin{array}{l}\text { the part of the merchant or } \\
\text { Platform user. }\end{array}$ \\
\hline 3. & $\begin{array}{l}\text { Takedown } \\
\text { Procedure }\end{array}$ & $\begin{array}{l}512 \text { (c) ( } 3 \text { ) (A) OCILLA } \\
\text { '(A) To be effective under } \\
\text { this subsection, a } \\
\text { notification of claimed } \\
\text { infringement must be a } \\
\text { written communication } \\
\text { provided to the } \\
\text { designated agent of a } \\
\text { service provider that } \\
\text { includes substantially the } \\
\text { following: (i) A physical or electronic } \\
\text { signature of a person } \\
\text { authorized to act on } \\
\text { behalf of the owner of an } \\
\text { exclusive right that is } \\
\text { allegedly infringed. } \\
\text { "(ii) Identification of the } \\
\text { copyrighted work claimed } \\
\text { to have been infringed, or, } \\
\text { if multiple copyrighted } \\
\text { works at a single online } \\
\text { site are covered by a } \\
\text { single notification, a } \\
\text { representative list of such } \\
\text { works at that site. } \\
\text { "(iii) Identification of the } \\
\text { material that is claimed to } \\
\text { be infringing or to be the } \\
\text { subject of infringing } \\
\text { activity and that is to be } \\
\text { removed or access to } \\
\text { which is to be disabled, } \\
\text { and information } \\
\text { reasonably sufficient to } \\
\text { permit the service } \\
\text { provider to locate the } \\
\text { material. (iv) reasonably sufficient to } \\
\text { '(i) }\end{array}$ & 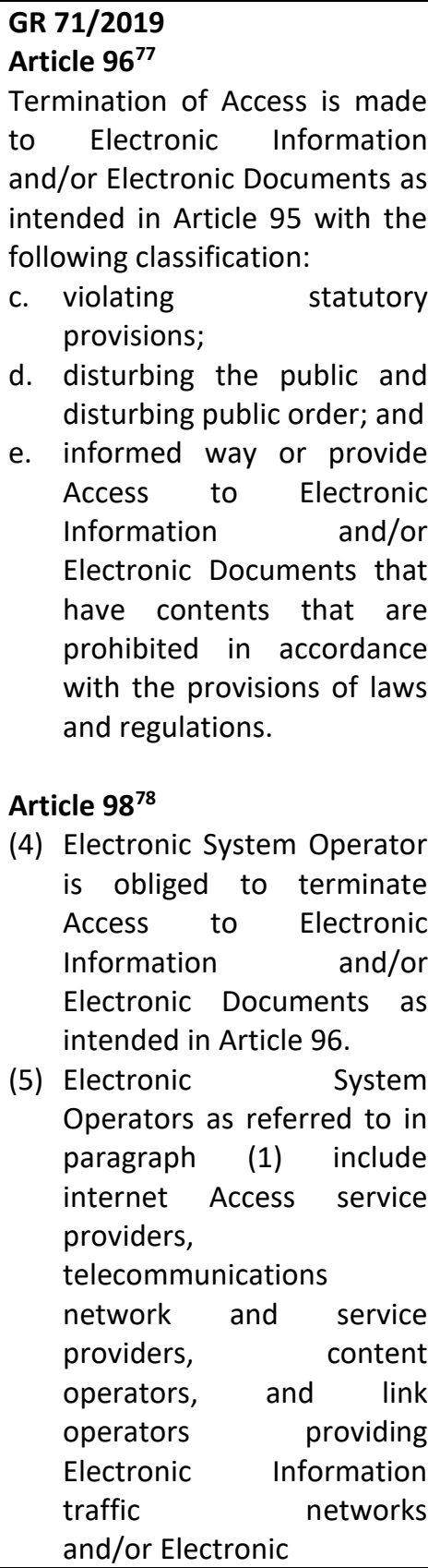 \\
\hline
\end{tabular}

17 U.S.C. § 512(c)(3)(A) (2006).

Article 96 of the Government Regulation Number 71 of 2019.

Article 98 of the Government Regulation Number 71 of 2019. 


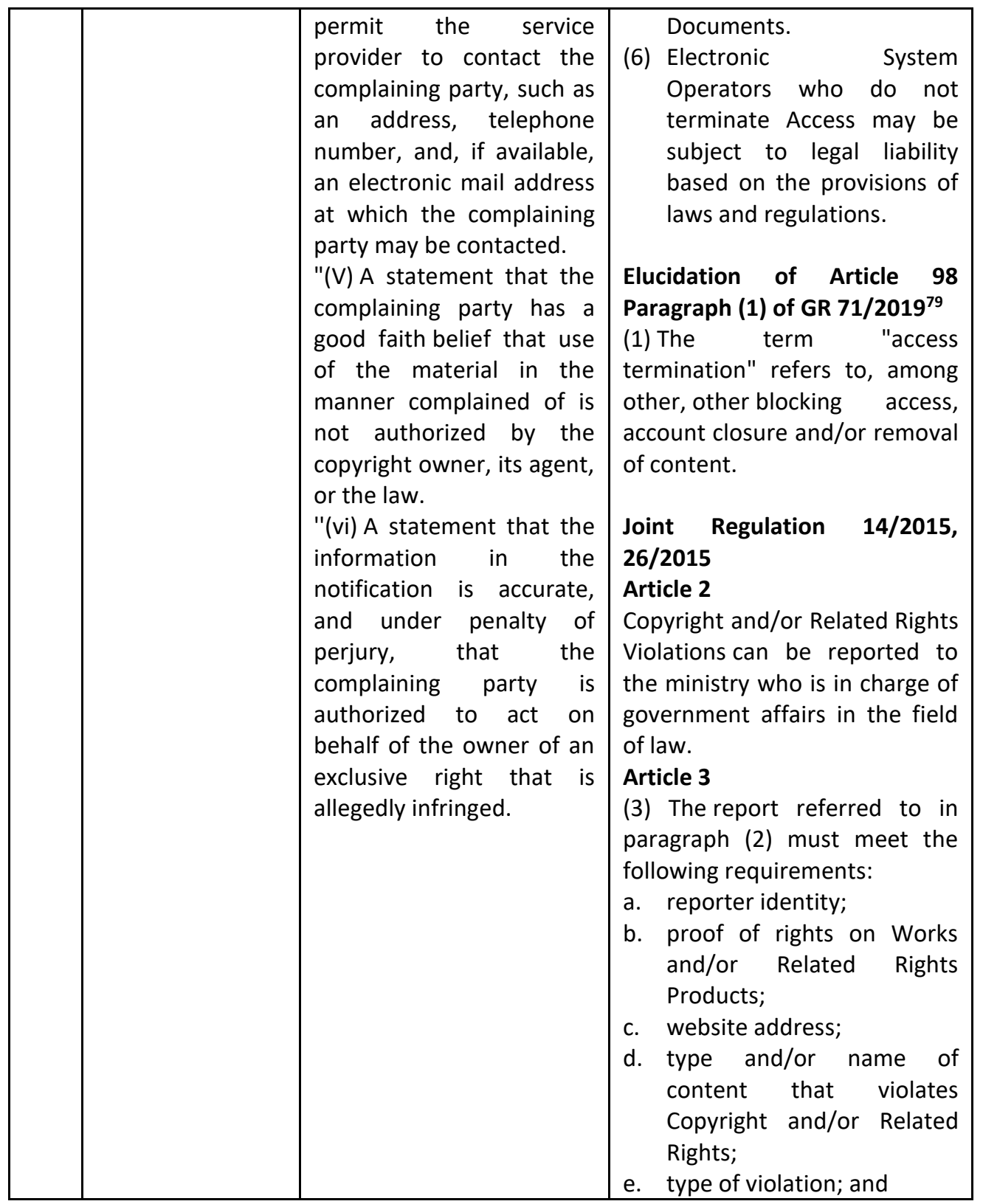

79 Elucidation of Article 96 the Government Regulation Number 71 of 2019, p. 92. 


\begin{tabular}{|l|l|l|}
\hline & & $\begin{array}{l}\text { f. other information related } \\
\text { to content that violates } \\
\text { Copyright and/or Related } \\
\text { Rights. }\end{array}$ \\
\hline
\end{tabular}

According to the table, identical provisions can be found in the protection of the copyright laws in both states. However, in detail, there are still deficiencies in the Indonesia's side.

Based on the first point, Indonesia has regulated the prohibition of destroying technological control facilities. However, a difference can be found, whereas under Article 1201.b1, the DMCA explicitly regulates the prohibition of importing goods or equipment with function to damage or render the control facilities of the created technology malfunctioning. In contrast, Indonesia's regulation does not regulated importation, production, and marketing of tools used to destroy technological control facilities. The absence of this provision is considered as a deficiency, because the marketing activities of the destructive tools are the leading way for related issues. ${ }^{80}$

Regarding Safe Harbor, the more general applicability of this provision as provided within the DMCA helps to understand the limits of responsibility for electronic system providers in general from violations that occur not due to their fault. Compared to Indonesia, the Safe Harbor provisions in Circular 5/2016 can only be applied to e-commerce in the form of UGC and it has no legally binding power. Thus, the requirements on limiting liability for electronic system operators from copyright infringement can only be referred to in Article 43 of the Copyright law, and Articles 96 and 98 of GR 71/2019. Unlike the Circular, those provisions are rather vague in regulating the standards for the Safe Harbor.

Lastly, regarding the takedown or access termination procedure. In this regard, the DMCA obliges electronic system providers to provide a means of reporting content that violates copyright laws. In Indonesia, the termination of access can only be done through the ministry, which then must go through a verification process by several ministries and institutions related to Copyright and/or Related Rights. ${ }^{81}$ This process certainly will consume a relatively lengthy process. Currently, there are no similar requirement for these obligations under Indonesian law for OTT providers, except for UGC based providers.

The existence of a broader scope of regulation is beneficial for protecting digital copyright, as seen from various copyright cases in the $\mathrm{US}^{82}$ and the protection technology to protect the copyrighted work. ${ }^{83}$ The difference is mainly due to the different concepts between the two. The DMCA has merged the concepts of

\footnotetext{
Article 1201.b1 DMCA; See also Moch Zairul Alam, op.cit, p. 113.

Article 8 Joint Regulation 14/2015, 26/2015.

Tana Pistorius and Odirachukwu S. Mwim, op.cit, p. 3.

Moch Zairul Alam, op.cit, p. 116.
} 
copyright protection and the digital world. On the other hand, the Indonesian Copyright Law still focuses on conventional protection. Other technical regulations are still needed to complement it.

The absence of a comprehensive legal framework supports Budhijanto's opinion that cyber law is a new legal regime whose activities need to be specifically regulated (sui generis), including copyright issues ${ }^{84}$ Therefore, the legal gaps under Indonesian law in digital copyright protection on OTT Streaming Content services still need improvement. Such improvement is possible through cooperation between platform stakeholders, the government, and the service's users.

\section{Practice of Digital Copyright Protection in OTT Streaming Content Services}

The legal protection of copyright in the providers of OTT services like Netflix is unique. Not only because of the new form but their status is often debated considering its "hitchhiking" nature through the internet, without requiring a physical form in respective country. This causes difficulties in the implementation of national law of countries where Netflix provides its services. Based on the principle of 'the place of incorporation', the OTT company is subject to the country's laws where it is established..$^{85}$ In contrast, the jurisdiction of copyright protection is valid territorially.

Netflix headquarter is in California, US. Therefore, Netflix is subject to the DMCA and in its practice, it has already adhered to the standards of copyright protection established in the regulation. In providing its content, Netflix partners with content providers to license streaming rights for various TV shows and films or to enter into agreements with copyright holders to distribute content on its platform. ${ }^{86}$ Netflix either produces its content or obtains exclusive rights to stream content called the Netflix Original, such as Orange is the New Black, Stranger Things, BoJack Horseman, Unbreakable Kimmy Schmidt, etc.

A license purchase allows Netflix to serve its content for viewing during a specified time in certain regions. In certain regions means that digital content that is licensed is limited to the territory of certain countries. Only countries with permit or license can broadcast the shows. For example, in Indonesia, Netflix purchase a

\footnotetext{
84 Danrivanto Budhijanto, Cyber Law dan Revolusi Industri 4.0, op.cit., p. 3.

85 Derita Prapti Rahayu, "Hukum Perdata Internasional Indonesia Bidang Hukum Keluarga (Family Law) dalam Menjawab Kebutuhan Global", Jurnal Hukum Progresif, Vol. XII, No. 1, 2018, p. 1994.

86 Hoh Jerick, "Netflix: A Binging Addiction Surrounding Intellectual Property", https://www.kass.com.my/articles/netflix-a-binging-addiction-surrounding-intellectual-property/, accessed February 2021.
} 
license of a film production company running in theaters for broadcast via Netflix for three years, specifically for countries in the Asia Pacific region. That way, the owner/copyright holder can receive royalties through the purchase of a license. Unfortunately, no CMI specifically collects royalties on cinematographic or film copyrights. Thus, royalty collection and management are still carried out independently by selling licenses from producers to Netflix. ${ }^{87}$

Based on the compliance with the three main provisions in the DMCA, the following facts are to be considered.

\section{a. Use of TPM}

To protect its contents, Netflix utilizes two main technologies to limit what people can do to films that are protected under copyright law, namely the Multi-Digital Rights Management and forensic watermarking. ${ }^{88}$ Digital Right Management (DRM) refers to access control technology used by publishers or copyright holders to restrict digital media use by controlling access, duplication, or conversion of copyrighted work objects to other formats. ${ }^{89}$ Multi-DRM refers to a license management feature that includes several DRM operators at the same time to strengthen its function. ${ }^{90}$

The technology makes it impossible for unauthorized users to play it with public video players even if they copy the content files. This copyrighted content is encrypted in an MP4 container, and if someone wants to view it anywhere else, they will only see a black screen. ${ }^{91}$

Then, the second technology is forensic watermarking. Conventional digital watermarking can be used to perform a copyright claim by inserting information about the copyright holder of the content. Meanwhile, forensic watermarking allows the insertion of user information and content so that it can be tracked in the event of illegal distribution from the user. ${ }^{92}$

\section{b. Compliance with The Safe Harbor Regulations}

The Safe Harbor requires the operator to carry out a reliable, safe, and responsible electronic system operation. If several appropriate actions have been taken, then the violation due to user error will no longer be the providers' fault. In Indonesia,

87 Gloria Imanuella (et.al.), "Pembagian Royalti Layanan Multimedia Video-On-Demand Netflix Ditinjau dari Undang-Undang Nomor 28 Tahun 2014 Tentang Hak Cipta”, Jurnal Ilmu Hukum Kyadiren, Vol. 6, No. 1, 2021, p. 37.

88 Ruoyu Wang (et.al.), "Steal This Movie - Automatically Bypassing DRM Protection in Streaming Media Services", 22nd USENIX Security Symposium, 2013, p. https://www.usenix.org/conference/usenixsecurity13/technical-sessions/paper/wang_ruoyu, accessed on February 2021.

89 Budi Agus Riswandi, Doktrin Perlindungan Hak Cipta di Era Digital, Yogyakarta: FH UII Press, 2016, p. 154.

90 Daniel Kim, "How Netflix protects its content - Part 1", https://medium.com/pallycon/how-netflix-protectscontents-part-1-a40508ed0001, accessed on February 2021.

91 Aditya Tiwari, "This is How your Favorite Netflix Movies and Shows are Pirated", https://fossbytes.com/howpirate-netflix-amazon-prime-movies-shows-piracy/, accessed on February 2021.

92 Daniel Kim, "How Netflix Protects Its Content - Part 2", 2019, https://medium.com/pallycon/how-netflixprotects-contents-part-2-33c1b60002a3, accessed on February 2021. 
the Safe Harbor guidelines are unenforceable and only applicable in the UGC type of e-commerce. Therefore, it will be more relevant to refer to the standards set out in the DMCA.

The standards can be met under several conditions. First, providers must adopt, implement fairly, and notify users about the policy to terminate the accounts of repeat infringers. Second, service providers must accommodate the standard technical measures copyright holders use to identify and protect copyrighted works. Third, the provider does not directly benefit financially from the infringing material. ${ }^{93}$

Considering that Netflix's revenue is mainly obtained through subscription fees for broadcasts, the third provision regarding financial benefits is inevitably inevitable if a copyright infringement is detected. However, this requirement should be fulfilled cumulatively. The first point of accountability will be charged to Netflix if they are not aware of potential violations there. This can also be fulfilled by providing avenues for reporting copyright infringement and responding to existing reports. For the second point, the utilization of technology that can identify and protect copyright works can also be a good practice in fulfilling Safe Harbor.

The first point is closely related to how Netflix gets its content, namely through licensing and enforcing agreements with copyright holders. In licensing, Netflix has obtained the content legally. In the event that a copyright infringement material in the contents that Netflix may not be aware of, possibly Netflix cannot be held responsible. Netflix has also provided a page for reporting violations of copyright content on the page How do I file a potential copyright infringement claim? that provides a form for reporting content that has the potential to infringe copyright. ${ }^{94}$ Apart from that, the DRM technology and forensic watermarking also assist to fulfill this requirement as a form of safe electronic system operation.

\section{c. Takedown Procedure}

Under the DMCA, a takedown of a work that deemed to infringe copyright can be requested to the provider directly, by providing:

1) the signature of the person who feels their rights have been infringed;

2) identification of the infringed copyright content;

93 Simon Frankel and Ethan Forrest, "How Does Livestreaming Video Fit into the DMCA's Safe Harbor?", https://news.bloomberglaw.com/tech-and-telecom-law/how-does-livestreaming-video-fit-into-the-dmcassafe-harbor, accessed on February 2021.

94 See Netflix, "How Do I File a Potential Copyright Infringement Claim?", https://help.netflix.com/en/node/24851, accessed on February 2021. 
3) information of the reporter to be contacted;

4) a statement that the reporting is made in good faith; and

5) a statement on the accuracy of the report and the authority to report.

In Indonesia, there is still no regulation mandating OTT providers to provide direct takedown procedure in their websites. Based on Article 98 of the Government Regulation Number 71 of 2019, the demand for access termination can only be submitted to the government instead of the provider.

As discussed earlier, Netflix also provides reporting services for infringing copyright content through the page How do I file a potential copyright infringement claim? The page offers a notification form for possible copyright infringement that contains:

1) reporter information, including name, company, address, and contact information;

2) information regarding copyright works, including a description of the infringement, the state where the violation happens, copyright holder information, and the location of the copyright content website; and

3) a statement of good faith, accuracy of information, willingness to continue reporting, as well as a place for the reporter's signature.

Comparing the items to the Takedown Procedure set by the DMCA, the required information fulfills the minimum requirements set under the act.

Based on the facts above, Netflix has provided sufficient protection for its contents as objects under the copyright law. In this digital era, violations, or at least the effort to do so, are unavoidable. Therefore, the protection will go a long way to prevent hacks. Even if the security system is hacked, the DRM technology will surely limit the object's misuse..$^{95}$ In addition, the reporting procedure is vital to allow the public to report a possible copyright infringement without the need to file a lawsuit, which will undoubtedly cost them more.

\section{E. Conclusion}

Technological developments have led to digitalization, and affect human activities. It correspondingly encourages the convergence of concepts leading to the emergence of telematics law and challenges the traditional copyright law. This can be seen in the digitalization of copyright objects which can be easily accessed through the internet. The convenience provides good benefits in terms of access, but it also increases the likelihood of breaches on the internet. Example of this can be seen from the emergence of the OTT Streaming Content Services that utilize digital copyright objects in the form of cinematographic work.

Compared to the US, the DMCA has merged the concept of copyright protection and the digital world. It is reflected under the three main points of the

95 Aditya Tiwari, loc.cit. 
regulation: the provisions for 'anti-circumvention,' safe harbor, and the takedown procedure. While it seems that Indonesia has similar arrangements, Indonesia's Copyright Law and cyberlaw regime have not regulated these three points adequately. In practice, Netflix as an OTT media that is subject to US law has implemented a good practice in protecting copyright objects by the procurement of copyright objects through licenses from copyright holders, the use of technology to protect objects of creation, and the reporting platform for copyright violation.

Based on the facts, it is necessary to amend the copyright law or to enact implementing legislation to protect digital copyright objects. The regulation is expected to provide legal certainty in the use of copyright object protection, especially for the OTT Streaming Content service. In addition, a cooperation among platform stakeholders, the government, and users is needed to provide more comprehensive regulations for the OTT media providers in Indonesia to ensure that, in the future, digital copyright protection will be based on binding positive laws.

\section{References}

\section{Books}

Ahmad Ramli, Hak Cipta, Disrupsi Digital Ekonomi Kreatif, PT Alumni, Bandung, 2018.

Askari Azikin and Yudha Purwanto, Video/TV Streaming dengan Audio Lan Project, Andi Offset, Yogyakarta, 2005.

Budi Agus Riswandi, Doktrin Perlindungan Hak Cipta di Era Digital, FH UII Press, Yogyakarta, 2016.

Danrivanto Budhijanto, Cyber Law dan Revolusi Industri 4.0, Logoz Publishing, Bandung, 2019.

Hukum Telekomunikasi, Penyiaran \& Teknologi Informasi:

Regulasi dan Konvergensi, PT Refika Aditama, Bandung, 2010.

Eddy Damian, Hukum Hak Cipta, PT Penerbit Alumni, Bandung, 2019.

Garner, Bryan A., Black's Law Dictionary, Seventh Edition, Thomson Reuters, St. Paul, 1999.

Groves, Peter (et.al), Intellectual Property and the Internal Market of the European Community, Graham \& Trotman, London, 1993.

Mochtar Kusumaatmadja, Pembinaan Hukum dalam Rangka Pembangunan Nasional, Penerbit Binacipta, Bandung, 1986. 
Muhammad Djumhana and R. Djubaedillah, Hak Milik Intelektual: Sejarah Teori dan Prakteknya di Indonesia, PT Citra Aditya Bakti, Bandung, 2003.

Lessig, Lawrence, Code Version 2.0, Basic Books, New York, 2006.

Free Culture: How Big Media Uses Technology and the Law to

Lock Down Culture and Control Creativity, Penguin Press, New York, 2004.

Litman, Jessica, Digital Copyright, Prometheus Book, New York, 2006.

Richard Burton Simatupang, Aspek Hukum dalam Bisnis, Rineka Cipta, Jakarta, 2007.

Tim Lindsey, (et.al), Hukum Kekayaan Intelektual, PT Alumni, Bandung, 2019

Yusran Isanaini, Hak Cipta dan Tantangannya di Era Cyber Space, Ghalia Indonesia,

Bogor, 2009.

\section{Other Documents}

Ayaz, Shaikh, "The Rise of OTT: Why 2020 was a Game-Changer for Streaming Aces Like Netflix and Amazon Prime Video", https://indianexpress.com/article/entertainment/opinion-entertainment/why2020-was-a-game-changer-for-streaming-aces-like-netflix-and-amazon-primevideo-7105424/.

Baldry, Shirley (et.al), "The Rise of OTT Players - What Is the Appropriate Regulatory Response?", $25^{\text {th }}$ European Regional Conference of the International Telecommunications Society (ITS): "Disruptive Innovation in the ICT Industries: Challenges for European Policy and Business", Brussels, Belgium, 22nd-25th June, 2014, International Telecommunications Society (ITS), 2014.

Beers, Brian, "How Netflix Pays for Movie and TV Show Licensing", https://www.investopedia.com/articles/investing/062515/how-netflix-paysmovie-and-tv-show-licensing.asp\#citation-6.

Bullich, Vincent and Thomas Guignard, "OTT Strategies and Regulations: Lessons from the US (2005-2015)", Quaderns del CAC 42, Vol. XIX, 2016.

Denico Doly, "Penegakan Hukum terhadap Pembuat Situs Streaming Film Bajakan", Vol. XII, No. 1, 2020.

Derita Prapti Rahayu, "Hukum Perdata Internasional Indonesia Bidang Hukum Keluarga (Family Law) dalam Menjawab Kebutuhan Global", Jurnal Hukum Progresif, Vol. XII, No. 1, 2018.

Diotalevi, Robert N., "The Digital Millennium Copyright Act", https://www.westga.edu/ distance/ojdla/summer32/diotalevi32.html.

Ellavie Ichlasa Amalia, "Awal Mula Netflix, dari Rental Film Fisik Sampai Digital", https://www.medcom.id/teknologi/news-teknologi/DkqD1gnb-awal-mulanetflix-dari-rental-film-fisik-sampai-digital.

Frankel, Simon and Ethan Forrest, "How Does Livestreaming Video Fit into the DMCA's Safe Harbor?", https://news.bloomberglaw.com/tech-and-telecomlaw/how-does-livestreaming-video-fit-into-the-dmcas-safe-harbor. 
Gloria Imanuella (et.al), "Pembagian Royalti Layanan Multimedia Video-OnDemand Netflix Ditinjau dari Undang-Undang Nomor 28 Tahun 2014 Tentang Hak Cipta", Jurnal Ilmu Hukum Kyadiren, Vol. 6, No. 1, 2021.

$\mathrm{Ha}$, Bui Thu, "ASEAN Report on OTT Project", ITU-ASEAN Forum on OTT Services: Business, Policy and Regulatory Trends 08-09 December 2015, Phnom Penh, Cambodia, 2015, https://www.itu.int/en/ITU-D/RegionalPresence/AsiaPacific/Documents/Events/2015/DecOTT/Presentations/Presentation\%20of\%20ASEAN\%200TT\%20project\%20THU\% 20HA.pdf.

Hagberg, J. Sundstrom (et.al), "The Digitalization of Retailing: An Exploratory Framework", International Journal of Retail \& Distribution Management, Vol. 44, No. 7, 2016.

Hasanuddin Sirait, "Sejarah Perkembangan Teknologi Telematika", 2009, http://astie.staff.gunadarma.ac.id/Downloads/files/50020/sejarahtelematika.pdf.

Jerick, Hoh, "Netflix: A Binging Addiction Surrounding Intellectual Property", https://www.kass.com.my/articles/netflix-a-binging-addiction-surroundingintellectual-property/, accessed February 2021.

Kemp, Simon, "Digital 2020: Global Digital Overview", 2020, https://datareportal.com/reports/digital-2020-global-digital-overview.

$$
\text { "Digital 2020: Indonesia", 2020, }
$$

https://datareportal.com/reports/digital-2020-indonesia.

Kim, Daniel, "How Netflix protects its content - Part 1", https://medium.com/pallycon/how-netflix-protects-contents-part-1a40508ed0001.

"How Netflix protects its content - Part 2", 2019, https://medium.com/pallycon/how-netflix-protects-contents-part-233c1b60002a3.

Kominfo, "UU Cipta Kerja Dukung Percepatan Transformasi Digital dan Ciptakan Lapangan Kerja Baru Sektor Kominfo, Siaran Pers No. 127/HM/KOMINFO/10/2020", 2020, https://www.kominfo.go.id/content/detail/29924/siaran-pers-no127hmkominfo102020-tentang-uu-cipta-kerja-dukung-percepatantransformasi-digital-dan-ciptakan-lapangan-kerja-baru-sektorkominfo/0/siaran_pers. 
Kramarsky, Stephen M., "Copyright Enforcement in the Internet Age: The Law and Technology of Digital Rights Management", DePaul Journal of Art, Technology \& Intellectual Property Law, Vol. 11, No. 1, 2001.

Lane, Charles K., "The DMCA's Safe Harbor Provision: Is It Really Keeping the Pirates at Bay?", Wake Forest Journal Of Business And Intellectual Property Law, Vol. 14, No. 1, 2013.

Leiner, Barry M. (et.al), "Brief History of the Internet 1997", 2017, https://www.internetsociety.org/internet/history-internet/brief-historyinternet/.

Moch Zairum Alam, "Perbandingan Perlindungan Sarana Kontrol Teknologi Atas Ciptaan Menurut Ketentuan Hak Cipta di Indonesia dan Amerika Serikat", Legal Spirit, Vol. 2, No. 1, 2018.

Mochammad Rizki, "Dukung TV Digital, Pemerintah Siapkan 5,37 Juta Set Top Box Gratis", 2020, https://www.nusantaratv.com/nasional/fokus/dukung-tv-digitalpemerintah-siapkan-537-juta-set-top-box-gratis.

Moskowitz, Dan, "Who Are Netflix's Main Competitors?", https://www.investopedia.com/articles/markets/051215/who-are-netflixsmain-competitors-nflx.asp.

Netflix, "How Do I File a Potential Copyright Infringement Claim?", https://help.netflix.com/en/node/24851.

PBwork, "Pros and Cons", dmca.pbworks.com/w/page/17963779/Pros\%20and\%20Cons.

Pujiyono and Sufmi Dasco Ahmad, "Legal Protection for Creators of Cinematographic Works against Copyright Infringement through Streaming and Free Download Sites", Journal of Legal, Ethical and Regulatory Issues, Vol. 2, No. 3, 2019.

Pistorius, Tana and Odirachukwu S. Mwim, "The Impact of Digital Copyright Law and Policy on Access to Knowledge and Learning", Journal of the Reading Association of South Africa, Vol. 10, No. 1, 2019.

Reidenberg, Joel R., "Lex Informatica: The Formulation of Information Policy Rules through Technology", Texas Law Review, Vol. 76, 1997.

Reis, João (et.al), "Digitalization: A Literature Review and Research Agenda", Proceedings on 25th International Joint Conference on Industrial Engineering and Operations Management - IJCIEOM, 2020.

Syrkin, Matthew, "U.S. Television on the Internet and the New "MVPDs" https://www.hugheshubbard.com/news/u-s-television-on-the-internet-andthe-new-mvpds-updated.

Scott, Mike, "Safe Harbors under the Digital Millennium Copyright Act", Legislation and Public Policy, Vol. 9, No. 99, 2005.

Tasya Safiranita Ramli (et.al), "Prinsip-Prinsip Cyber Law Pada Media Over the Top E-Commerce Berdasarkan Transformasi Digital di Indonesia", Jurnal Legislasi Indonesia, Vol. 16, No. 3, 2019. 
Tiwari, Aditya, "This Is How Your Favorite Netflix Movies and Shows Are Pirated", https://fossbytes.com/how-pirate-netflix-amazon-prime-movies-shows-piracy/. Wang, Ruoyu (et.al), "Steal This Movie - Automatically Bypassing DRM Protection in Streaming Media Services", 22nd USENIX Security Symposium, 2013, https://www.usenix.org/conference/usenixsecurity13/technicalsessions/paper/wang_ruoyu.

Wayne, Michael L., "Netflix, Amazon, and Branded Television Content in Subscription Video On-Demand Portals", Media, Culture \& Society, Vol. 40, No. 5, 2017.

Wahab, Sazali Abdul, "Defining the Concepts of Technology and Technology Transfer: A Literature Analysis", International Business Research, Vol. 5, No. 1, 2012.

Yunus, Aida Suraya Md. (et.al), "Use of Webcasting Technology in Teaching Higher Education", International Education Journal, Vol. 7, No. 7, 2006.

\section{Legal Documents}

World Intellectual Property Organization (WIPO) Copyright Treaty 1996.

Digital Millennium Copyright Act 1998.

The Law Number 11 of 2008 on Electronic Information and Transactions [UndangUndang Nomor 11 Tahun 2008 tentang Informasi dan Transaksi Elektronik].

The Law Number 19 of 2016 on the Amendment to the Law Number 11 of 2008 on Electronic Information and Transactions [Undang-Undang Nomor 19 Tahun 2016 tentang Perubahan Atas Undang-Undang Nomor 11 Tahun 2008 tentang Informasi dan Transaksi Elektronik].

The Law Number 28 of 2014 on Copyright [Undang-Undang Nomor 28 Tahun 2014 tentang Hak Cipta].

The Government Regulation Number 71 of 2019 on the Implementation of Electronic Systems and Transactions [Peraturan Pemerintah Nomor 71 Tahun 2019 tentang Penyelenggaraan Sistem dan Transaksi Elektronik].

The Regulation of the Minister of Communication and Information Number 9 of 2017 on the Implementation of Content Providing Services on Cellular Mobile Networks [Peraturan Menteri Komunikasi dan Informatika Nomor 9 Tahun 2017 tentang Penyelenggaraan Jasa Penyediaan Konten pada Jaringan Bergerak Seluler].

The Joint Regulation of the Minister of Law and Human Rights and the Minister of Communication and Information Number 14 of 2015 and Number 26 of 2015 
on the Implementation of Closure of Content and/or Access Rights of User of the Copyright Violation and/or Related Rights in Electronic System [Peraturan Bersama Menteri Hukum dan Hak Asasi Manusia dan Menteri Komunikasi dan Informatika Nomor 14 Tahun 2015 dan Nomor 26 Tahun 2015 tentang Pelaksanaan Penutupan Konten dan/atau Hak Akses Pengguna Pelanggaran Hak Cipta dan/atau Hak Terkait dalam Sistem Elektronik].

The Circular Letter of the Ministry of Communication and Information Technology Number 3 of 2016 on the Provision of Application Services and/or Content through the Internet (Over the Top) [Surat Edaran Kementerian Komunikasi dan Informatika Nomor 3 Tahun 2016 tentang Penyediaan Layanan Aplikasi dan/atau Konten Melalui Internet (Over the Top)].

The Circular Letter of the Ministry of Communication and Information Technology Number 5 of 2016 on the Limitations and Responsibilities of Platform Providers and Merchants of E-Commerce Using User-Generated Content Platforms [Surat Edaran Kementerian Komunikasi dan Informatika Nomor 5 Tahun 2016 tentang Batasan dan Tanggung Jawab Penyedia Platform dan Pedagang (Merchant) Perdagangan Melalui Sistem Elektronik (Electronic Commerce) yang Berbentuk User Generated Content].

Constitutional Court Decision Number 39/PUU-XVIII/2020 on the Review of the Law Number 32 of 2002 on Broadcasting against the 1945 Constitution of the Republic of Indonesia [Putusan Mahkamah Konstitusi Nomor 39/PUUXVIII/2020 Perihal Pengujian Undang-Undang Nomor 32 Tahun 2002 tentang Penyiaran terhadap Undang-Undang Dasar Negara Republik Indonesia Tahun 1945]. 